\title{
Role of Serum Transferrin Receptor in Diagnosing and Differentiating Iron Deficiency Anemia from Anemia of Chronic Disease in Patients with Chronic Kidney Disease
}

\author{
Latif $\mathrm{A}^{\mathrm{a}}$, Alam MR ${ }^{\mathrm{b}}$, Khanam Ac ${ }^{\mathrm{c}}$, Hoque F ${ }^{\mathrm{d}}$, Rahim MA ${ }^{\mathrm{e}}$, Islam $\mathrm{RN}^{\mathrm{f}}$
}

\begin{abstract}
Background: Anemia is common in patients with chronic kidney disease (CKD) and this is generally anemia of chronic disease, but iron deficiency anemia (IDA) is also common. Soluble transferrin receptor (sTfR) is a useful marker for IDA. Present study was undertaken to assess the utility of STfR as a marker of IDA in selected group of Bangladeshi patients with CKD.

Methods: This cross-sectional study was conducted in the Department of Nephrology, BSMMU, Dhaka, Bangladesh from January 2013 to December 2014. Patients with anemia admitted in nephrology department whether on hemodialysis or not and medicine department of BSMMU were taken for study. The study population was further divided into two groups; Group A, patients who are having IDA and Group B, patients with ACD and a control group was also selected. Data were collected by face to face interview and laboratory investigations with a self-administered questionnaire.

Results: The mean age of the patients in two study groups were $38.40 \pm 13.23$ and $34.85 \pm 10.52$ years respectively and male-female ratio were 0.5:1 and 1:0.5. Mean sTfR level was higher $(4.81 \pm 1.64 \mu \mathrm{g} / \mathrm{ml})$ in patients with IDA than $(2.89 \pm 1.40 \mu \mathrm{g} / \mathrm{ml})$ in patients with $A C D(p<0.0001)$. In our study mean ferritin level was $599.59 \pm$ $449.15 \mu \mathrm{g} / \mathrm{L}$ in $A C D$ patients whereas $101.23 \pm 119.42$ in IDA patients $(p<0.0001)$. Total iron binding capacity (TIBC) was more in ACD patients with sTfRe" $3 \mu \mathrm{g} / \mathrm{ml}$ as compared to ACD patients with sTfR $<3 \mu \mathrm{g} / \mathrm{ml}$. Transferrin saturation (TSAT) level was significantly decreased in ACD patients with $s T f R \geq 3 \mu \mathrm{g} / \mathrm{ml}$ as compared to ACD patients with $s T f R<3 \mu \mathrm{g} / \mathrm{ml}$.

Conclusion: sTfR has a comparable ability to S. ferritin in diagnosing IDA and ACD. However, sTfR and serum ferritin alone cannot definitely exclude co-existing iron deficiency in ACD. As sTfR is not affected by infection and/or inflammation, thus providing a non-invasive alternative to bone marrow study.
\end{abstract}

Key words: Anemia; anemia of chronic disease; CKD; ferritin; iron deficiency anaemia; soluble transferrin receptor.

(BIRDEM Med J 2017; 7(2): 132-137)

Author Information

a Dr. Abdul Latif, Registrar, Nephrology \& Dialysis Unit-3, BIRDEM, Dhaka

b Dr. Muhammad Rafiqul Alam, Professor, Nephrology, BSMMU, Dhaka

c Prof. Asia Khanam, Professor of Nephrology, BSMMU, Dhaka

d Dr. Farhana Hoque, Associate Professor, Physiology, Kumudini Women's Medical College, Mirzapur, Tangail

e Dr. Muhammad Abdur Rahim, Assistant Professor, Nephrology \& Dialysis Unit-1, BIRDEM, Dhaka

f Dr. Rafi Nazrul Islam, Assistant Registrar, Nephrology \& Dialysis Unit-2, BIRDEM, Dhaka

Address of correspondence: Dr. Abdul Latif, Registrar, Nephrology \& Dialysis Unit-3, BIRDEM General Hospital, 122 Kazi Nazrul Islam Avenue, Shahbag, Dhaka-1000, Bangladesh. Email: 1tfmn7879 @gmail.com

Received: July 25, 2016

Accepted: February 28, 2017

\section{Introduction}

Chronic kidney disease (CKD) is an important chronic, non-communicable epidemic disease. Up to $80 \%$ of patients with CKD may have anaemia. ${ }^{1}$ CKD patients suffer from various types of anemia including iron deficiency anemia (IDA) and anemia of chronic disease (ACD). These are two common forms of anemia that have interrelated characteristics, causing a diagnostic predicament. ACD is characterized by hypoferremia in the presence of adequate reticulo-endothelial iron stores. Absolute or functional iron deficiency is present in 25$38 \%$ of patients with anemia of CKD. ${ }^{2}$ Serum ferritin and transferrin saturation (TSAT) are two most commonly done tests used for evaluating IDA. However, these tests do not consistently reflect the iron status of patients with CKD on hemodialysis. ${ }^{3}$ Serum ferritin and transferrin are considerably influenced by acute phase responses in 
inflammation. Total iron binding capacity (TIBC) is a negative acute phase reactant. Moreover, TSAT fluctuates because of diurnal variation in serum iron levels.

In recent years, soluble transferrin receptor (sTfR) has been introduced as a sensitive, early and valuable new marker of iron depletion. ${ }^{4}$ sTfR is a truncated form of the transferrin receptor present on erythroblasts in bone marrow and many other cells. As sTfR concentration is not usually affected by inflammation or infection but in conditions where iron deficiency co-exists with ACD, STfR raises secondary to underlying iron deficiency.

The present study was undertaken to assess the utility of sTfR as a marker of iron deficiency anemia in CKD patients whether on or not on hemodialysis.

\section{Methods}

This cross-sectional study was conducted in the Department of Nephrology of Bangabandhu Sheikh Mujib Medical University (BSMMU), Dhaka, Bangladesh from January 2013 to December 2014. A total of 70 adult ( $>18$ years) male and non-pregnant female patients with anemia, admitted in Nephrology and Medicine Department of BSMMU were purposively included in this study. A total of 30 age matched healthy subjects were also included as control. Selected subjects were evaluated clinically and by laboratory parameters and data were recorded in structured questionnaire. Selected patients were subjected to do following tests: complete blood count with erythrocyte sedimentation rate, red blood cell indices, reticulocyte count, peripheral blood film (PBF), iron profile (serum total iron, ferritin, total iron binding capacity, transferrin saturation), Creactive protein (CRP) and sTfR. sTfR was done by particle enhanced immunoturbidimetric assay; (Roche/ Hitachi analyzers, Cat. No. 12148315). Serum CRP was done by using latex agglutination test using kit CRP
Latex CHEMELEX. Complete blood count was done using Sysmex KX21 autoanalyzer and serum creatinine by enzymatic method on autoanalyzer. Serum ferritin was estimated by immunoradiometric assay and serum iron by colorimetric assay at $560 \mathrm{~nm}$.

Data were analyzed by using statistical package for social science (SPSS) Version 20 for Windows. Numerical data were expressed as mean \pm standard deviation and number (percentage) as appropriate. Unpaired Student's t test, Mann-Whitney 'U' test, Chi squared test (Fisher exact modification) and ANOVA ' $\mathrm{F}$ ' test and ANOVA (Post hoc) were performed to calculate statistical difference and/or association between groups, as appropriate. A $p$-value $<0.05$ was taken as significant.

Patients were divided into 2 groups: Group A: patients with IDA $(n=30)$ having a serum ferritin level of $<200$ $\mathrm{ng} / \mathrm{ml}$ (in patients on haemodialysis) and $<100 \mathrm{ng} / \mathrm{ml}$ in non-haemodialysis CKD subjects ${ }^{5}$. Group B consisted of patients with $\operatorname{ACD}(n=40)$ defined as those having a chronic disease persisting for more than two months who were anaemic with a CRP of $>6 \mathrm{ng} / \mathrm{ml}$. A third group (Group C) consisting of healthy controls were also kept in the study. Patients with hematological malignancies, hemolytic anemia, history of acute blood loss, recent blood transfusion, active infection, receiving iron supplementation within 1 month were excluded from the study. Here, expected value of sTfR was 2.2$5.0 \mu \mathrm{g} / \mathrm{ml}$ (Roche/Hitachi analyzers) in normal subjects.

\section{Results}

Total patients were 100 including 70 study subjects and 30 controls. Study subjects were divided into Group-A (IDA), Group-B (ACD) and Group-C (Controls). Age, sex and body mass index (BMI) of the patients are presented in Table I.

Table I. Base-line characteristics of the study subjects

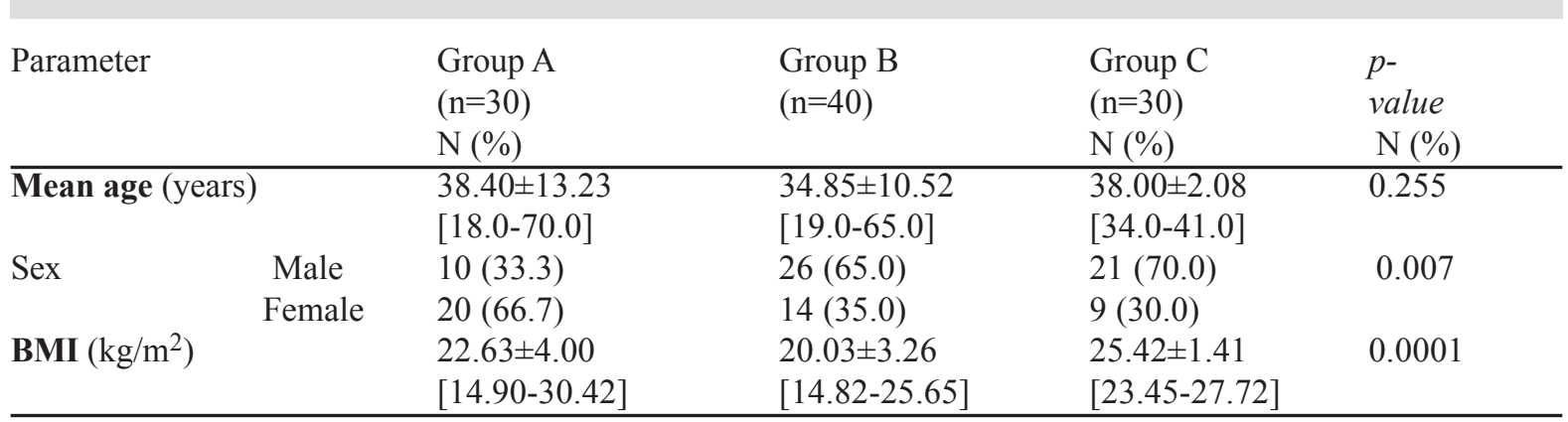

ANOVA ' $F$ ' test and Chi-squared test were performed to calculate statistical difference and/or association as applicable. Different parameters of red cell indices and reticulocyte counts are presented in Table II. 
Table II. Red blood cell indices and reticulocyte count of the study subjects

\begin{tabular}{lllll}
$\begin{array}{l}\text { Parameter } \\
(\mathrm{n}=30)\end{array}$ & $\begin{array}{l}\text { Group A } \\
(\mathrm{n}=40)\end{array}$ & $\begin{array}{l}\text { Group B } \\
(\mathrm{n}=30)\end{array}$ & Group C & $p$-value \\
\hline Haemoglobin $(\mathrm{g} / \mathrm{dl})$ & $8.29 \pm 1.20$ & $7.88 \pm 1.22$ & $14.15 \pm 0.88$ & 0.0001 \\
& {$[5.6010 .10]$} & {$[5.709 .80]$} & {$[12.9015 .50]$} & \\
RBC $\left(\mathrm{X} 10^{12} / \mathrm{L}\right)$ & $3.04 \pm 0.49$ & $2.76 \pm 0.40$ & $4.88 \pm 0.30$ & 0.0001 \\
& {$[2.073 .76]$} & {$[1.903 .26]$} & {$[4.385 .34]$} & \\
Het $(\mathrm{L} / \mathrm{L})$ & $0.25 \pm 0.04$ & $0.24 \pm 0.04$ & $0.43 \pm 0.04$ & 0.0001 \\
& {$[0.170 .32]$} & {$[0.140 .30]$} & {$[0.400 .50]$} & \\
MCV (fl) & $79.99 \pm 7.29$ & $84.37 \pm 10.43$ & $88.10 \pm 3.26$ & 0.001 \\
& {$[62.0092 .00]$} & {$[54.8094 .00]$} & {$[83.0092 .00]$} & \\
MCH (pg) & $25.29 \pm 2.65$ & $27.20 \pm 3.98$ & $29.10 \pm 1.16$ & 0.0001 \\
& {$[19.0028 .00]$} & {$[18.6030 .00]$} & {$[27.0031 .00]$} & \\
MCHC (g/dl) & $30.85 \pm 0.78$ & $31.89 \pm 1.09$ & $33.30 \pm 0.65$ & 0.0001 \\
& {$[30.0032 .00]$} & {$[30.0034 .00]$} & {$[32.0034 .00]$} & \\
Reticulocyte count $(\%)$ & $1.81 \pm 0.33$ & $1.90 \pm 0.40$ & $1.93 \pm 0.10$ & 0.328 \\
& {$[0.842 .24]$} & {$[1.402 .78]$} & {$[1.822 .10]$} & \\
\hline
\end{tabular}

ANOVA ' $F$ ' test were performed to calculate statistical difference and/or association as applicable.

$\mathrm{RBC}=$ Red blood cell

Hct $=$ Haematocrit

$\mathrm{MCV}=$ Mean corpuscular volume

$\mathrm{MCH}=$ Mean corpuscular haemoglobin

$\mathrm{MCHC}=$ Mean corpuscular haemoglobin concentrationSerum iron, total iron binding capacity, ferritin and transferrin saturation are presented in Table III.

Table III. Iron profile of the study subjects

\begin{tabular}{lllll} 
Parameter & $\begin{array}{l}\text { Group A } \\
(\mathrm{n}=30)\end{array}$ & $\begin{array}{l}\text { Group B } \\
(\mathrm{n}=40)\end{array}$ & $\begin{array}{l}\text { Group C } \\
(\mathrm{n}=30)\end{array}$ & $\mathrm{p}$ value \\
\hline Serum iron $(\mu \mathrm{g} / \mathrm{dl})$ & $45.67 \pm 16.63$ & $52.40 \pm 23.20$ & $90.20 \pm 22.59$ & $0.193^{*}$ \\
& {$[16.0077 .00]$} & {$[21.0098 .0$} & {$[48.00132 .00]$} & $\begin{array}{l}0.0001^{* *} \\
0.0001^{* * *}\end{array}$ \\
& $326.80 \pm 22.64$ & $221.80 \pm 44.23$ & $278.87 \pm 54.38$ & $0.0001^{*}$ \\
TIBC $(\mu \mathrm{g} / \mathrm{dl})$ & {$[292.00356 .00]$} & {$[144.0302 .00]$} & {$[168.00364 .00]$} & $0.0001^{* *}$ \\
& $101.23 \pm 119.42$ & $599.59 \pm 449.15$ & $83.73 \pm 45.09$ & $0.001^{* * *}$ \\
Serum ferritin $(\mu \mathrm{g} / \mathrm{L})$ & {$[14.50515 .00]$} & {$[240.001936 .00]$} & {$[55.20214 .84]$} & $0.818^{* *}$ \\
& $16.47 \pm 6.47$ & $28.02 \pm 12.30$ & $27.50 \pm 6.22$ & $0.0001^{* * *}$ \\
& & & & \\
TSAT $(\%)$ & {$[7.5033 .00]$} & {$[10.2051 .00]$} & {$[14.0037 .00]$} & $0.0001^{* *}$ \\
& & & & $0.816^{* * *}$ \\
\hline
\end{tabular}

* Group A vs Group B, ** Group A vs Group C, *** Group B vs Group C

ANOVA 'F' test and ANOVA (Post Hoc) were performed to calculate statistical difference and/or association as applicable. 
Soluble transferrin receptor levels of different groups are shown in Table IV.

Table IV. Soluble transferrin receptor (sTfR) of the study subjects

\begin{tabular}{llccc} 
Parameter & $\begin{array}{l}\text { Group A (IDA) } \\
(\mathrm{n}=30)\end{array}$ & $\begin{array}{l}\text { Group B (ACD) } \\
(\mathrm{n}=40)\end{array}$ & $\begin{array}{c}\text { Group C } \\
(\mathrm{n}=30)\end{array}$ & p value \\
\hline $\mathbf{s T f R}(\mu \mathrm{g} / \mathrm{ml})$ & $4.81 \pm 1.64$ & $2.89 \pm 1.40$ & $2.96 \pm 0.78$ & \\
& {$[3.3610 .30]$} & {$[0.935 .51]$} & {$[2.104 .57]$} & 0.0001 \\
\hline Group A vs Group B & & & & 0.0001 \\
Group A vs Group C & & & & 0.829
\end{tabular}

ANOVA 'F' test and ANOVA (Post hoc) were performed to calculate statistical difference and/or association as applicable.

Mean sTfR higher in Group A compared to Group B and $\mathrm{C}$ and showed significant difference $(\mathrm{p}=0.0001)$. However, comparison between group $\mathrm{B}$ and $\mathrm{C}$ did not show any significant difference $(\mathrm{p}=0.829)$

Table V. Iron profile status in subgroups of ACD

\begin{tabular}{llll} 
Iron status & $\begin{array}{l}\text { Group } B_{1} \\
\text { sTfR }<3(\mathrm{n}=24)\end{array}$ & $\begin{array}{l}\text { Group } B_{2} \\
\operatorname{sTfR} \geq 3(\mathrm{n}=16)\end{array}$ & p value \\
\hline Serum iron $(\geq \mathrm{g} / \mathrm{dl})$ & $62.00 \pm 23.25$ & $38.00 \pm 14.22$ & 0.0001 \\
TIBC $(\geq \mathrm{g} / \mathrm{dl})$ & $198.50 \pm 41.38$ & $256.75 \pm 16.99$ & 0.0001 \\
TSAT $(\%)$ & $31.17 \pm 11.62$ & $23.30 \pm 12.10$ & 0.157 \\
Serum ferritin $(\geq \mathrm{g} / \mathrm{ml})$ & $665.58 \pm 495.88$ & $500.61 \pm 360.65$ & 0.279 \\
\hline
\end{tabular}

Data were expressed as mean $\pm \mathrm{SD}$ and Mann-Whitney ' $U$ ' test were performed to calculate statistical difference and/or association as applicable.

Group $B_{1}$ : Anemia of chronic disease (ACD) with $\mathrm{sTfR}<3 \geq \mathrm{g} / \mathrm{ml}$

Group $B_{2}$ : Anemia of chronic disease (ACD) with $\operatorname{sTfR} \geq 3 \mu \mathrm{g} / \mathrm{ml}$

\section{Discussion}

It is difficult to evaluate anemia in patients with inflammation as conventional laboratory tests for iron status are often unable to differentiate ACD from IDA. S.ferritin is the most commonly used single laboratory test to diagnose iron deficiency as its concentration is roughly proportional to the iron stores, but there is no agreement on the lowest reference value for absent iron stores in the presence of ACD as its level increases in response to underlying inflammation. sTfR is derived from the erythroid precursors in the bone marrow and from the reticulocytes, so it reflects the rate of erythropoiesis. The serum level of sTfR in iron deficiency also increases due to up regulated transferrin receptor on the cell surface in response to increased cellular demand. Thus, it is assumed that sTfR reflects the tissue iron supply reliably.
sTfR can be used to discriminate IDA from ACD and inflammation. sTfR level appears to be specific and sensitive marker of iron deficiency and enjoys the advantages over serum ferritin as serum ferritin being an acute phase protein, is increased in inflammatory disorders. ${ }^{4}$

sTfR levels are expected to be highest in IDA as reported earlier by Dimitriou et al $(2000)^{6}$, by Malope et $\mathrm{al}(2001)^{7}$ in their study of 561 pre-school children and also by Angeles et al (2006) $)^{8}$ and Hanif et al $(2005)^{9}$ in different studies. In another study by Jain et al 2009, ${ }^{10}$ all 21 IDA patients had significantly raised sTfR levels. In our study mean sTfR level was higher (4.81 \pm 1.64 $\mu \mathrm{g} / \mathrm{ml})$ in patients with IDA than $(2.89 \pm 1.40 \mu \mathrm{g} / \mathrm{ml})$ in patients with ACD. In control group, sTfR value was low ( $2.96 \pm 0.781 / 4 \mathrm{~g} / \mathrm{ml}$ ) as same as ACD group which reflect it was not affected by inflammation or infection. 
In a study by Jain et al (2009) ${ }^{10} \mathrm{~S}$. Ferritin level was significantly higher in ACD patients than IDA patients which was similar to current study. In this study mean ferritin level was $599.59 \pm 449.15 \mu \mathrm{g} / \mathrm{L}$ in ACD patients whereas $101.23 \pm 119.42 \mu \mathrm{g} / \mathrm{L}$ in IDA patients and also ferritin is lower in control group $(83.73 \pm 45.09 \mu \mathrm{g} / \mathrm{L})$ than IDA group. It has been shown that, ferritin values increased in IDA with CKD patients may be due to chronic inflammatory process. In a study Gupta et al $(2009)^{11}$ the serum ferritin was much higher in patients with CKD than in patients with IDA without CKD.

ACD cases were further divided into 2 subgroups based on sTfR level of $3 \mu \mathrm{g} / \mathrm{ml}$. Serum Iron levels were almost same in the two subgroups. TIBC was more in ACD patients with sTfR $\geq 3 \mu \mathrm{g} / \mathrm{ml}$ as compared to ACD patients with $\mathrm{sTfR}<3 \mathrm{ug} / \mathrm{ml}$. TSAT level was significantly lower in ACD patients with $\mathrm{sTfR} \geq 3 \mu \mathrm{g} /$ $\mathrm{ml}$ as compared to ACD patients with $\mathrm{sTfR}<3 \mu \mathrm{g} / \mathrm{ml}$. Serum ferritin was less in ACD patients with $\mathrm{sTfR} \geq 3 \mu \mathrm{g} /$ $\mathrm{ml}$ as compared to ACD patients with $\mathrm{sTfR}<3 \mu \mathrm{g} / \mathrm{ml}$.

In addition to describing the sTfR level and ferritin in level, we found the other investigation in differentiating IDA and ACD. Hb, MCV and MCH were decreased in both the groups. However, the decrease in $\mathrm{MCH}$ and MCV was much more in IDA as compared to ACD whereas the decrease in $\mathrm{Hb}$ was much more in $\mathrm{ACD}$ as compared to IDA. In a study by Jain et al (2009) ${ }^{10}$ the findings were opposite to our findings. This difference may be due to the study was conducted among the children under 18 years of age in India.

S. Iron was reduced in both IDA and ACD patients. Mean serum iron in patient with IDA was $45.67 \mu \mathrm{g} / \mathrm{dl}$ and $52.40 \mu \mathrm{g} / \mathrm{dl}$ in patient with ACD; however, there was no significant difference between IDA and ACD groups. TIBC was significantly increased and TSAT was significantly reduced in IDA as compared to ACD. Similar findings were observed in a study by Jain et al $(2009)^{10}$ conducted in India. In another study by Gupta et al (2009) ${ }^{11}$ found that the mean value of serum iron in CKD patients was higher than IDA patients whereas TIBC was lower in CKD patients with higher TSAT values.

In our study, we found mean age of patients with IDA and patients with ACD respectively were $38.40 \pm 13.23$ years and $34.85 \pm 10.52$ years whereas male and female ratio among IDA and patients with ACD respectively were $0.5: 1$ and 1:0.5. In study by Gupta et al (2009) ${ }^{11}$ the mean age was $48.56 \pm 16.34$ years in the study group and $45.91 \pm 17.45$ years in the control group. In another study by Chen $\mathrm{Y}$ et al $(2006)^{5}$ mean age was $(58 \pm 14$ versus $60 \pm 14$ years) while sex distribution (men, $52 \%$ versus $48 \%)$.

\section{Conclusion}

In present study, mean sTfR level is higher in patients with IDA than in patients with ACD and control. sTfR level of ACD was much close to control group. S. Ferritin level was significantly high in ACD patients than IDA patients.

Thus, it is important to estimate serum sTfR and to be able to differentiate pure IDA, ACD and ACD with coexisting iron deficiency thus providing a non-invasive alternative to bone marrow iron.

Declaration: This paper has been presented in World Congress of Nephrology, Mexico, 2017.

\section{References}

1. Talwar VK, Gupta HL,Shashinarayan. Clinico haematological profile in chronic renal failure. J Assoc physician India 2002;50:228-33

2. National kidney foundation. Kidney Disease outcomes quality initiative: clinical practice guidelines for anaemia of chronic kidney disease. IV NKF-K / DOQI, update 2000;37:S 182238.

3. Moreb J, Popovtzer MM, Friedlaender MM, Konjin AM, Hershko C, Evaluation of iron status in patients on chronic hemodialysis: Relative usefulness of bone marrow hemosiderin, serum ferritin, transferrin saturation, mean corpuscular volume and red cell protoporphyrin. Nephron 1983; 35: 196-200.

4. Saboor M, Moinuddin, Noreen A. Soluble transferrin receptor: a differentiating marker between iron deficiency anaemia and anaemia of chronic disorders, J Ayub Med Coll Abbottabad 2011;23(3): 75-80.

5. Chen Y, Hung S,\& Tarng D. Association Between Transferrin Receptor-Ferritin Index and Conventional Measures of Iron Responsiveness in Hemodialysis Patients , American Journal of Kidney Diseases 2006;47 (6):1036-44.

6. Dimitrou H, Stiakaki E, Markaki EA. Soluble transferrin receptor levels and soluble transferrin receptor/ log ferritin index in the evaluation of erythropoietic status in childhood infections and malignancy. Acta Paediatr 2000; 89: 1169-73.

7. Malope BL, Macphail AP, Albert M, Hiss DC. The ratio ofserum transferrin receptor and serum ferritin in diagnosis of iron status.Br J Haematol 2001; 115: 84-89. 
8. Angeles Vazquez Lopez M, Molonis FL, Carmona ML, Morales AC, Munoz Vico FJ, Munoz JL et al. Serum transferrin receptor in children: usefulness for determining the nature of anemia in children. J Pediatr Hematol Oncol 2006; 28: 809-15.

9. Hanif E, Ayyub M, Anwar M, Ali W, Bashir M. Evaluation of serum transferrin receptor concentration in diagnosis and differentiating iron deficiency anemia from anem ia of chronic disorders. J Pak Med Assoc 2005; 55: 13-16.

10. Shilpa Jain, Shashi Narayan, Jagdish Chandra, Sunita Sharma, Sonal Jain and Priya Malhan,Evaluation of Serum Transferrin
Receptor and sTfR Ferritin Indices in Diagnosing and Differentiating Iron Deficiency Anemia from Anemia of Chronic Disease Indian J Pediatr 2010; 77 (2): 179-83.

11. Gupta S, Uppal B, Pawar B. Is soluble transferrin receptor a good marker of iron deficiency anemia in chronic kidney disease patients? Indian Journal of Nephrology 2009; 19 (Issue 3):225-30

12. DeGruchy's Clinical Heamatology in Medical Practice Edited by Frank Firkin Colin hesterman, David penington \& Bryan Rush . 5th edition, Wiley India Pvt. Limited, India 2008; $350-55$. 